Original Research

\title{
The Implementation of Therapeutic Communications with Postoperative Patient Satisfaction in Islamic Hospital of Sultan Agung Semarang
}

\author{
Alif Wahdatin, Dyah Wiji Puspita Sari and Muh. Abdurrouf \\ Departmen of Nursing Science, Sultan Agung Islamic University, Indonesia
}

\begin{abstract}
Introduction: Weaknesses in applying therapeutic communication are still a problem for nurses. This affects the quality of nursing services that have an impact on patient satisfaction. The purpose of this study was to identify the relationship between therapeutic communication and postoperative patient satisfaction.

Methods: This research method was an analytical survey method used a cross sectional approach. Respondents in this study were postoperative patients who were treated in RSISA inpatient ward with 127 patients. Sampling technique that use was simple random sampling. The data analysis technique in this study used the Spearman test.

Results: The results showed that the majority characteristics of respondents had female $61.4 \%$, age 50-64 (33.8\%), employment of private employees $24.4 \%$, senior secondary education $37.0 \%$. The results also showed that most therapeutic communication was in the good category $(54.3 \%)$ and patient satisfaction in the category was very satisfied (52.8\%). The results of this research showed that there was significant relationship between therapeutic communication and postoperative patient satisfaction with $\mathrm{p}$-value 0,000 ( $\mathrm{p}$-value $<0.05$ ).

Conclusion: The implications of this research can be a reference in increasing the ability of nurse therapeutic communication so that patient satisfaction with nursing services increases.
\end{abstract}

\section{ARTICLE HISTORY}

Received: Dec 26, 2019

Accepted: Dec 31, 2019

\section{KEYWORDS}

Therapeutic; communication; postoperative; patient satisfaction

\section{CONTACT}

Dyah Wiji Puspita Sari

$\square$ daiyah 04@yahoo.com

$\Xi$ Departmen of Nursing Science,

Sultan Agung Islamic University,

Indonesia

Cite this as: Wahdatin, A., Sari, D.W.P., \& Abdurrouf, M. (2019). The Implementation of Therapeutic Communications with Postoperative Patient Satisfaction in Islamic Hospital of Sultan Agung Semarang. Jurnal Ners, 14(3si), 378-382. doi:http://dx.doi.org/10.20473/in.v14i3(si).17219

\section{INTRODUCTION}

A hospital organization consists of various members whose communication with one another may result in conflicts. Because of the typical urgency of tasks, smooth communications among departments and colleagues in relation to patients are essential in a hospital (Kim, 2011; O'Connell \& Gardner, 2012). Nurses comprise most staff in most hospitals and come into contact with other hospital staff and departments most frequently. All activities related to patients, the main customers of a hospital, are conducted through nurses (Dinh, Walker, Parameswaran, \& Enright, 2012). (Lee, 2008)

Weakness in communication is still a problem for nurses and patients because the nursing process does not run optimally and causes patient discomfort. Patients often complain about nursing services where service is unsatisfactory and makes patients angry, this is sometimes due to misunderstanding of communication with nursing staff who do not understand the intent of the message conveyed by the patient (Sya'diyah, 2013).

Good nurse communication will enhance the image of professionalism in him. Conversely, if nurse communication is not good, this will affect the client's assessment of the nurse. Because in communication, especially therapeutic communication, there are several characteristics of a nursing staff needed to solve problems and facilitate therapeutic growth. Honesty (trustworthy) which is owned by a nurse, expressive in delivering messages, is positive so that patients feel cared for by nurses, have an attitude of empathy and not sympathy, are able to see patient problems from the patient's point of view, sensitive to 
the patient's feelings, not affected by the past clients and nurses themselves.

The result of the research from (Park, Jeoung, Lee, \& Sok, 2015) show that Affiliation and time of worse duty each had a significant impact on self-efficacy. Positive correlations The degrees of communication competence and selfefficacy of ER nurses were good, with higher scores than the median values. Religious affiliation and previous participation in communication education each had a significant impact on communication competence. Religious were identified among communication competence, self-efficacy, and job satisfaction (Park et al., 2015).

The difference in individual communication of each nurse has a direct impact on one's behavior (Ivanovich, Konopaske, \& Matteson, 2007). Gibson in Farida (2011) explains that there are three individual variables. The nurse's performance in question is one of them is the application of therapeutic communication. Job performance decreases with age. Age also affects a person in intrapersonal relationships. Men and women have uniquely different communication styles. Physically between men and women are different, parenting is different, the style of speech is different, even the tone of voice is different. Education affects the individual mindset influences a person's behavior (Asmadi, 2008). The duration of work influences nurses in developing communication skills because a lifetime experience will continue to grow throughout his professional career (Sheldon, 2013).

Patient satisfaction is one of the important indicators that must be considered in health services. Patient satisfaction is the result of assessment of patients on health services by comparing what is expected in accordance with the reality of health services received in a health order in the hospital (Kotler, 2007). Thus patient satisfaction at the hospital depends on how the service provided by the hospital. But the services provided are still not in accordance with what is desired by the patient and patient satisfaction is still not in accordance with the standard.

Measuring nursing care quality has been recognized as a priority for healthcare providers and policymakers. There are two critical factors indicating the need to measure nursing care quality. First, nurses represent the largest segment of healthcare professionals, and therefore measuring nursing care quality is critical to improving practice (Freitas, Silva, Minamisava, Bezerra, \& Sousa, 2014). Second, measuring nursing care quality is a necessary step in determining the level of success that healthcare systems achieve in providing high-quality, high-value care in an equitable manner (Freitas et al., 2014).

The low number of patient satisfaction will have an impact on the development of the hospital. In patients who feel dissatisfied with health services received, the patient decides to move to another hospital that can provide better services (Abdel Maqsood, Oweis, \& Hasna, 2012)(Kotler, 2007).
The results of Darmawan's study (2009) with the title "The Relationship between Therapeutic Communication Implementation and Client Satisfaction in Obtaining Nursing Services in Emergency Services at Dr Soedarso Hospital Pontianak West Kalimantan" stated that most of the nurses in the Emergency Installation District General Hospital Dr. Soedarso Pontianak has implemented therapeutic communication and client satisfaction about nursing services is satisfied, there is a meaningful relationship between the implementation of therapeutic communication with the level of client satisfaction about nursing services. It is also in line with the research of Nugroho and Aryati (2009) about "Therapeutic Nurse Communication Relations with Patient Satisfaction in Kendal Islamic Hospital. The results showed that the average value of patient satisfaction was $57.4 \%$.

\section{MATERIALS AND METHODS}

This research is a quantitative research that uses a cross sectional design where variables including risk factors and variables including effects factors are observed and related variables are measured and at the same time or at one time (Chandra, 2008).

Respondents in this study were inpatients at least 3 days at Sultan Agung Islamic Hospital Semarang. This research was conducted in November 2018 as many as 127 respondents.

The instrument of this study used a demographic questionnaire, therapeutic communication questionnaire and patient satisfaction questionnaire. The demographic questionnaire contains the patient's identity which includes: Gender, Age, Education, Occupation, and length of stay.

The patient satisfaction questionnaire consisted of 25 statements with favorable and unfavorable forms using a likert scale, ie each item was valued for a very dissatisfied answer (STP) value 1, dissatisfied (TP) value 2 , quite satisfied $(C P)$ value 3 , satisfied $(P)$ value of 4 and very satisfied (SP) value 5 . Result of assessment Not satisfied: 25-58 Satisfied: 59-92 Very satisfied 93-125.

Therapeutic communication questionnaire consists of 13 statements where the statement has been tested for validity with no answer $(\mathrm{TP})=1$, Occasionally $(\mathrm{SK})=2$, Sometimes $(\mathrm{KK})=3$, Often $(\mathrm{S})$ $=4$, Always $(S)=5$. Result of assessment: Never: 1330, Often: 31-47, Always: 48-65.

The validity and reliability test of this instrument was carried out at the Sultan Agung Islamic Hospital in 42 respondents. Test the validity in this study using the Pearson product moment technique. The validity test conducted by researchers on the research instrument shows that all statement items on the patient satisfaction instrument are valid. This is indicated by the results of $r$ count greater than $r$ table (0.304). Whereas in therapeutic communication instruments, it is found that 7 (seven) invalid items are item no. $7,8,11,12,13,15,20$, because $r$ count is smaller than $r$ table $(0.304)$ so that the item is 
declared not valid and cannot be used (deleted). Reliability test using Cronbach's Alpa, the results obtained that the two valid instruments are indicated by the value of Cronbach's Alpa 0.971 for the patient satisfaction instrument, and 0.824 for therapeutic communication.

\section{RESULTS}

\section{Characteristics of Respondents}

Table 1. Respondent Frequency Distribution Based on Gender, Age, Work, and Education Patients in the ward on December $2018(\mathrm{n}=127)$

\begin{tabular}{lcc}
\hline \multicolumn{1}{c}{ Variable } & Frequency(f) & $\begin{array}{c}\text { Percentage } \\
\text { (\%) }\end{array}$ \\
\hline Gender & 78 & \\
Female & 49 & 61,4 \\
Male & & 38,6 \\
Age & 15 & \\
17-24 & 19 & 11,8 \\
25-34 & 39 & 15 \\
35-49 & 43 & 30,7 \\
50-64 & 11 & 33,8 \\
65> & & 8,7 \\
Work & 16 & \\
Students & 9 & 12,6 \\
Goverment employees & 31 & 7,1 \\
Private employees & 17 & 24,4 \\
Laborer & 28 & 13,4 \\
Traders & 26 & 22 \\
unemployment & & 20,5 \\
Education & 35 & 27,6 \\
Elementari School & 37 & 29,1 \\
Junior High school & 47 & 3,9 \\
Senior High school & 3 & \\
Diploma & & \\
Bachelor & & \\
\hline & & \\
\hline
\end{tabular}

Patient Satisfaction

Table 2 Respondent Frequency Distribution Based on Patient Satisfaction in the ward on December $2018(\mathrm{n}=127)$

\begin{tabular}{lcc}
\hline Patient Satisfaction & Frequency (f) & $\begin{array}{c}\text { Percentage } \\
(\%)\end{array}$ \\
\hline Not satisfied & 3 & 2,4 \\
Satisfied & 57 & 44,9 \\
Very satisfied & 67 & 52,8 \\
\hline Total & 127 & 100 \\
\hline
\end{tabular}

\section{Therapeutic Communication}

Table 3 Frequency Distribution of Respondents Based on Therapeutic Communication in the ward on December $2018(\mathrm{n}=127)$

\begin{tabular}{lcc}
\hline $\begin{array}{l}\text { Therapeutic } \\
\text { Communication }\end{array}$ & $\begin{array}{c}\text { Frequency } \\
\text { (f) }\end{array}$ & Percentage (\%) \\
\hline Never & 2 & 1,6 \\
Often & 56 & 44,1 \\
Always & 69 & 54,3 \\
\hline Total & 127 & 100 \\
\hline
\end{tabular}

\section{DISCUSSION}

Table 1 shows that out of 127 respondents based on sex, the highest number of respondents was female with 78 respondents with $61.4 \%$ percentage while 49 respondents with the least number were male patients with $38.6 \%$ percentage.

Women are more emotional than men because women are more easily offended, easily affected, very sensitive, highlight feelings, and easily vent, while men are not emotionally very objective, not easily affected, easily separate between thoughts and feelings so that sometimes they are less sensitive and able to harbor feelings (Dagun, 2002).

Men and women have differences in doing work and in communication, Robbins (2008) revealed that there are differences in abilities between men and women in the relationship between humans where women have a higher sensitivity in interpreting signs of communication than men.

The results of this study indicate that women are psychologically more sensitive than men, in communicating always use feelings, so that the power of emotion influences the way of self-control in showing ability and ability to foster a healing motivation within him.

Table 1 shows that from 127 respondents based on age the results of the highest respondents aged 50-64 years were 43 respondents with a percentage of $33.8 \%$, while respondents who were at least 65 years old were as many as 11 respondents with a percentage of $8.7 \%$.

Age is a person's life span until his last birthday (Tampubolon, 2008). Davis (2004) states that age> 35 years old is categorized as old age and age $\leq 35$ years old.

The results of this study indicate that age is very influential with postoperative term younger age because the modern lifestyle of an unhealthy society creates many diseases without realizing it. Age has a very important role in determining the pattern of thinking, the higher the age of a person will be more mature in taking a decision or action to be carried out, where the early adult age still think has a responsibility and a big role in the family, thereby strengthening motivation to recover.

Table 1 shows that from 127 respondents based on work the results of the respondents were mostly private employees 31 with a percentage of $24.4 \%$ while the respondents were the least namely public servants 9 with a percentage of $7.1 \%$.

Someone who has worked and in the work environment, there is work stress which is the tension that is often experienced by employees that can interfere with work situations and concentration in completing tasks. The emergence of these tensions is essentially influenced by three factors, namely the problem of the organization of the work environment, individual employee factors and other matters relating to the community (Griffin, Hogan, Lambert, Tucker-Gail, \& Baker, 2010) Robert, 2010 in Eunike). 


\section{Bivariate Analysis}

Table 4. Cross Table of Relationships between Therapeutic Communication and Post-Operation Patient Satisfaction in the ward on December $2018(\mathrm{n}=127)$

\begin{tabular}{|c|c|c|c|c|c|c|c|c|}
\hline \multirow{3}{*}{$\begin{array}{l}\text { Therapeutic } \\
\text { Communication }\end{array}$} & \multicolumn{7}{|c|}{ Patient Satisfaction } & \\
\hline & \multicolumn{2}{|c|}{ Not satisfied } & \multicolumn{2}{|c|}{ satisfied } & \multicolumn{2}{|c|}{ Very satisfied } & & \\
\hline & $\mathrm{f}$ & $\%$ & $\mathrm{f}$ & $\%$ & $\mathrm{f}$ & $\%$ & $\mathrm{~F}$ & $\%$ \\
\hline Never & 2 & 1,6 & 0 & 0 & 0 & 0 & 2 & 1,6 \\
\hline Often & 0 & 0 & 50 & 39.4 & 6 & 4.7 & 56 & 44.1 \\
\hline Always & 1 & 0.8 & 7 & 5.5 & 61 & 48 & 69 & 54.3 \\
\hline Total & 3 & 2.4 & 57 & 44.9 & 67 & 52.8 & 127 & 100 \\
\hline
\end{tabular}

The results of this study indicate that the majority of respondents work status as private employees because people who have worked have more tendency to utilize health services. In line with the concept, the results of this study some respondents work as private employees so they are more required to be creative with work pressure and higher stress burden.

Table 1 shows that out of 127 respondents based on education the results of the most respondents were high school educated as many as 47 respondents with a percentage of $37.0 \%$ while respondents the least educated DIPLOMA were 3 respondents with a percentage of $2.4 \%$.

People who are knowledgeable with less education, need more special attention to medical services. The low level of education can result in low community visits to health care services. Someone who has high knowledge and education has some desire for goods and services so they try to fulfill according to the knowledge they have in achieving satisfaction, (Tjiptoherijanto, 1994 in Budiman, Suhat, Helina, 2010).

The majority of the education of middle and upper secondary respondents have attention to his health is better when compared to the level of primary education so that if he is sick he will immediately seek treatment. The level of education influences the perception of satisfaction and utilization of health service facilities, the higher the level of education, the higher the intensity of the utilization of health services (Sulistyorini, 2012 in fachrizal, 2014).

The results of this study indicate that the number of respondents with high school education is more than the elementary school, junior high school, PT (college). One's education influences one's thinking and reasoning power where understanding something is someone who has a low education, this also influences the curiosity and use of available services such as health services, highly educated people better understand the use of existing services.

Table 2 shows that out of 127 respondents based on patient satisfaction, the majority of patients had patient satisfaction with the highest category of 67 respondents with percentage $52.8 \%$, while patients who had the least category were not satisfied as many as 3 respondents with a percentage of $2.4 \%$.

Patient satisfaction is related to the quality of hospital services. Patient satisfaction with nursing care is considered a principal outcome indicator of quality of care (Laschinger, Hall, Pedersen, \& Almost, 2005), and it is seen as an important aspect for evaluating and improving overall healthcare (Dudkiewicz, 2014; Koy, Yunibhand, \& Angsuroch, 2016). As nurses provide the key aspects of healthcare, their contribution influences significantly the level of patient satisfaction with the overall healthcare services provided. (De-La-Cueva-Ariza et al., 2014; Laschinger et al., 2005)

Providing satisfaction to patients can only be obtained if the company pays attention to things that are desired by patients (Nursalam, 2011). Paying attention to what the patient wants means the quality of service produced is determined by the patient. By knowing the level of patient satisfaction, hospital management can improve service quality in improving patient satisfaction (Chahal, 2008).

Nurse therapeutic communication is indicated by four aspects, namely aspects of authenticity, aspects of empathy, aspects of respect or respect and concrete aspects (Nurjannah, 2005). The higher each aspect, the higher therapeutic communication will be, therapeutic communication is not just verbal communication but also non verbal communication.

In good therapeutic communication there are several stages namely pre-interaction, orientation stage, work phase and termination stage. In this research, therapeutic communication stages are discussed, namely at the orientation stage, here the researcher assesses how when the nurse first meets the patient and how the attitude shown by the nurse to the patient, so that the patient feels satisfied with the nurse's performance and therapeutic communication.

This study concluded that communication would be very helpful not only for patients but also for medical staff. For medical staff information about patients is very important to determine the diagnosis and treatment. Patients communicate can issue complaints that they face at the same time is a form of treatment, because not infrequently patients feel satisfied and relieved after channeling to the other side.

The results of the cross table in table 4 found that therapeutic communication in the category never with patient satisfaction in the category of dissatisfaction of 2 respondents (1.6\%), therapeutic communication in the category often with patient 
satisfaction in the satisfied category of 56 respondents (44.1\%), and Therapeutic communication in the category always with patient satisfaction in the very satisfied category of 69 respondents (54.3\%).

The results of the analysis of therapeutic communication relationship with postoperative patient satisfaction at Sultan Agung Hospital in Semarang obtained $p$ value in the spearman rank test of $0,000(p<0.05)$ which means that there is a relationship between therapeutic communication and postoperative patient satisfaction at RSI Sultan Agung Semarang, while the correlation coefficient between the two variables is 0.552 , meaning that the closeness between the two variables is moderate, where the increase in $\mathrm{Y}$ value is followed by an increase in the value of $X$. It means the better therapeutic communication to the patient, the higher patient satisfaction, the lower the therapeutic communication patient about nursing therapeutic communication.

\section{CONCLUSION}

Therapeutic communication with postoperative satisfaction in Sultan Agung Semarang Islamic Hospital has moderate closeness. Having a meaningful positive relationship in the same direction if therapeutic communication is good, the satisfaction of postoperative patients can increase, this is true for the opposite, if postoperative satisfaction increases, therapeutic communication will also be good. High patient satisfaction is supported by good hospital services, especially therapeutic communication, so that patients feel comfortable.

\section{ACKNOWLEDGMENT}

The author wish thank to Nursing Science Faculty of Sultan Agung Islamic University for the trust, support and for sponsoring the researcher to do this research.

\section{REFERENCES}

Abdel Maqsood, A. S., Oweis, A. I., \& Hasna, F. S. (2012). Differences between patients' expectations and satisfaction with nursing care in a private hospital in Jordan. International Journal of Nursing Practice. https://doi.org/10.1111/j.1440172X.2012.02008.X

Chahal, H. (2008). Predicting Patient Loyalty and Service Quality Relationship: A Case Study of Civil Hospital, Ahmedabad, India. Vision: The Journal of Business Perspective. https://doi.org/10.1177/0972262908012004 05

Dagun, M. S. (2002). Psikologi keluarga (peranan ayah dalam keluarga). Jakarta: PT Rineka Cipta.
De-La-Cueva-Ariza, L., Romero-García, M., DelgadoHito, P., Acosta-Mejuto, B., Jover-Sancho, C., Ricart-Basagaña, M. S. O. S. C. T., ... Solà-Ribó, M. (2014). Development of an instrument to measure the degree of critical patient's satisfaction with nursing care: Research protocol. Journal of Advanced Nursing. https://doi.org/10.1111/jan.12184

Dudkiewicz, P. B. (2014). Utilizing a Caring-based Nursing Model in an Interdepartmental Setting to Improve Patient Satisfaction. International Journal of Human Caring. https://doi.org/10.20467/1091-5710.18.4.30

Freitas, J. S. de, Silva, A. E. B. de C., Minamisava, R., Bezerra, A. L. Q., \& Sousa, M. R. G. de. (2014). Quality of nursing care and satisfaction of patients attended at a teaching hospital. Revista Latino-Americana de Enfermagem. https://doi.org/10.1590/01041169.3241.2437

Griffin, M. L., Hogan, N. L., Lambert, E. G., Tucker-Gail, K. A., \& Baker, D. N. (2010). Job involvement, job stress, job satisfaction, and organizational commitment and the burnout of correctional staff. Criminal Justice and Behavior. https://doi.org/10.1177/0093854809351682

Koy, V., Yunibhand, J., \& Angsuroch, Y. (2016). The quantitative measurement of nursing care quality: a systematic review of available instruments. International Nursing Review. https://doi.org/10.1111/inr.12269

Laschinger, H. S., Hall, L. M. G., Pedersen, C., \& Almost, J. (2005). A psychometric analysis of the patient satisfaction with nursing care quality questionnaire: An actionable approach to measuring patient satisfaction. Journal of Nursing Care Quality. https://doi.org/10.1097/00001786200507000-00006

Lee, H. S. (2008). Relationships among communication competence, communication types, organizational commitment of nurses (Unpublished master's thesis). Dankook University, Cheonan-si, Republic of Korea.

Nurjannah, I. (2005). Komunikasi terapeutik (Dasardasar Komunikasi Bagi Perawat). Yogyakarta: Mocomedia.

Park, M. S., Jeoung, Y., Lee, H. K., \& Sok, S. R. (2015). Relationships among communication competence, self-efficacy, and job satisfaction in korean nurses working in the emergency medical center setting. Journal of Nursing Research. https://doi.org/10.1097/jnr.00000000000000 59

Sheldon, K. . (2013). Komunikasi untuk Keperawatan: Berbicara dengan Pasien (2nd ed.). Jakarta: Erlangga. 